\title{
Attitudes and Perceptions of Teachers Towards Code-switching in the EFL College Classrooms of Sindh, Pakistan
}

\author{
Arfa Memon \\ English Language Development Center, Mehran University of Engineering \& Technology, Jamshoro \\ Dr. Habibullah Pathan \\ English Language Development Center, Mehran University of Engineering \& Technology, Jamshoro \\ Syed Waqar Ali Shah \\ English Language Development Center, Mehran University of Engineering \& Technology, Jamshoro \\ Quratulain Talpur \\ Mehran University of Engineering and Technology, Shaheed Zulfiqar Ali Bhutto Campus Khairpur
}

\begin{abstract}
This quantitative descriptive study investigates the attitudes in general and perceptions of college teachers towards the functional category of code-switching. Research data was collected through a survey questionnaire, which was comprised of 24 items. Attitude items were scaled as negative and positive; however, the functional category has three components: Curriculum Access, Classroom Management, and interpersonal relationship. Collected data were analyzed through SPSS software using percentage and mode. Code-switching is a natural phenomenon that occurs in bilingual and multilingual classrooms in Pakistan. However, the medium of instruction in Pakistan's classrooms is English. Participants for this study were 50 EFL college teachers from 20 different colleges of Sindh Pakistan; in them, 31 (62\%) were male, and 19 (38\%) were female. It was found that; code-switching is being used extensively in the EFL college classrooms of Sindh for different reasons. Almost all the teachers who participated in the study have positive attitudes towards code-switching. According to the results of survey results, teachers' do not deny code-switching in teaching in learning. Results conclude that Teachers use code-switching as a teaching technique to compensate the students' limited expertise in the target language. Educational officials and policymakers must recognize and make appropriate adjustments to overcome the constraints in the current curriculum.
\end{abstract}

Keywords: Code-switching, EFL classrooms, Attitudes, Perceptions, Code-switching functions.

DOI: $10.7176 /$ JLLL/78-05

Publication date: April $30^{\text {th }} 2021$

1. Introduction:

In the past, code-switching had become an essential topic of research studies in the sociolinguistic field of foreign language analysis. Lately, Code-switching has resumed considerable attention. Lin (2008) describes code-switching in the classroom setting as two or multiple linguistics codes alternatively used by teachers and students. Martin says (2005, p.89) "Code-switching," Provide creative, pragmatic and safe practices for classroom participants, between native and target language.

The study of the use of language in society, in particular, has become an important phenomenon because it is part of the process of development and multiple language use. It offers the most evident synchronous proof that communication occurs in communities and for an individual in a bilingual and multilingual setting. Codeswitching is typically used during foreign language learning and teaching processes, considerably while learning English based on diverse backgrounds and reasons. (Yusuf, 2009)

\subsection{Context of the Study:}

English became de facto the official language of Pakistan in 1947. At this time, English and Urdu are used for the official purposes of the country. However, English is the medium of instruction in the educational sectors of Pakistan. The acknowledgement of linguistic diversity must be given priority. The opportunity to communicate in many languages will be of great benefits for individuals. It will boost innovation and educational perceptions, promote thinking outside the box, help students learn without fear, and give an exceptional understanding of the subject.

\subsection{Problem Statement:}

English as a medium of instruction in various countries, used as a foreign language, generally causes frustration for both teachers and students (Ahmed \& Zareef, 2013). The challenge encountered by students is the lack of content knowledge and language skills. In some cases, Teachers also fail to deliver content knowledge and 
language skills to the students.

\subsection{Aim \& Objectives of the Study:}

This research aims to understand and analyze the attitudes and perceptions of college teachers towards Codeswitching and its use in EFL Classrooms in Sindh, Pakistan.

Following are the study objectives:

- To investigate the general attitudes of college teachers towards the practices of code-switching in the EFL classrooms.

- To investigate the perceptions of college teachers towards using code-switching in the functional category of Pakistani EFL classrooms.

\subsection{Study Purpose:}

This study helps in understanding why the use of other minority languages in the EFL classrooms is crucial. This study emphasizes that CS serves pedagogical purposes and encourages learners' to participate and teachers' to manage and organize the classroom. It promotes the EFL process of teaching and learning.

\subsection{Study Limitation:}

The study is limited to EFL college classrooms of Sindh only; also, the study is only focused on the teachers, students' involvement would have different results to the study.

\section{Literature Review:}

Research shows that Code-switching is a global phenomenon that occurs in diverse social and educational settings (Van der Walt, 2009)

There is clear evidence that educators would use L1 despite any instructional context and national guidance.

Code-Switching is regarded as favorable by some scholars, including Lin (2008), Mahofa and Adendorf (2014). They say that Code-Switching has tremendous potential to help bilingual teachers' meet context-specific learning outcomes.

On the contrary, some language scholars consider Code-Switching as unfavorable, arguing that it indicates a linguistic inability or a tactic for compensating reduced competence and the unsystematic consequence of not being well aware of at least one of the languages involved.

Worldwide research was conducted in 111 countries, with 2785 teachers (Hall, 2012 \& Cook, 2013). The findings revealed that English Language Teaching (ELT) classrooms commonly use L1. Teachers said that students find it better to use L1 to explain ambiguous grammar and vocabulary. The researchers recognized L1 role as a developer of a positive environment in the classroom. However, Cheng (2013) advised that despite the everyday use of Code-switching, L1 could only be utilized in a controlled way to clarify the complicated grammar rules and complex linguistic principles.

Chowdhury (2012) has uncovered that code-switching plays a constructive function in Bangladeshi Language classrooms. It is utilized to retain discipline, instruct the learners on different assignments, direct them, or concentrate on an important topic to achieve the desired effect.

In their research, he Set al (2019), which was carried out in Singapore, tested the effect of codeSwitching on the language of bilingual children and their cognitive progress. As a result, Code-Switching has been found to contribute favorably and significantly to children's cognitive flexibility. These results reveal the multifaceted effect of Code-Switching on the early development of children. However, findings revealed that teachers usually switch code more frequently as a habit than for educational purposes.

Younas et al. (2020), the study explores the impact of code-switching on ESL students in Pakistan. The study results show meaningful use of code-mixing and frequency in mixing those words, phrases, and the shortest units of language in a foreign language. Besides, the results reveal that ESL teachers also use Codeswitching. This research suggests that Code-switching is used to improve bilingual learners' comprehension and participation.

\section{Research methodology:}

Introduction:

In this section, all the methods are mentioned, which were being implied in this study.

\subsection{Framework:}

Myers-Scotton's (1993) theory of the Markedness Model supports this study. This model characterizes the social inferences of a specific dialect choice concerning members' dedication and is a prominent model in codeswitching study.

The speakers demonstrate their comprehension of a situation by using a specific language, which means 
that the decisions or choices made by speakers depend on the speakers' situations and roles within the setting. (Smith, 2002)

\subsection{Research approach:}

Quantitative descriptive research design is the best suitable design to get answers to research questions. A descriptive statistical method approach will be used, which utilizes both quantitative and qualitative elements, for the analysis of the population sample. None of the variables is affected in any way in descriptive studies.

\subsection{Research Instrument:}

A 5-Likert Scale questionnaire survey was used to collect data for the study. The questionnaire consisted of 24 items, ten were related to negative and positive attitudes, and 14 items were about the functions of codeswitching in the EFL classrooms. The questionnaire was adopted from the study of (Joanna, 2014).

\subsection{Pilot study:}

A pilot study was conducted to check the reliability of the questionnaire; pilot study participants were 16 college EFL college teachers'. The pilot study participants' were later excluded from the main study. The Cronbach alpha score for the study was 0.9 recorded, which is the better score to use as a data collection tool.

\subsection{Participants \& Sampling:}

The participants for this study were 50 EFL Govt. college teachers, 38 were male, and 19 were female teachers'. 20 different Govt. college teachers' filled the questionnaire. Snowball sampling will be used to collect data from the participants; it is also named chain referral sampling (Biernacki \& Waldorf, 1981) it is a type of convenient sample.

\subsection{Data Collection:}

For the convenience of participants and researchers, two ways were used for data collection. Data was collected through distributing the face-to-face survey and also by sending Google forms link.

3.7. Data Analysis: Data was analyzed through SPSS using percentages and mode to summarize the data.

4. Results \& Discussion:

Objective 1: EFL college teachers Attitudes towards code-switching

$\mathrm{S}-\mathrm{A}=$ strongly agree (5), A= Agree (4), U-D= Undecided (3), D=Disagree (2), S-D= strongly disagree (1)

\begin{tabular}{|c|c|c|c|c|c|c|c|}
\hline NO & As an EFL teacher, I view that & S-A & $\mathbf{A}$ & U-D & D & S-D & Mode \\
\hline 1. & C-S will facilitates the language learning process & $28 \%$ & $48 \%$ & $14 \%$ & & $10 \%$ & 4 \\
\hline 2. & $\begin{array}{l}\text { The Use of C-S will increase the students' dependency and } \\
\text { reliance on the teachers }\end{array}$ & $4 \%$ & $56 \%$ & $24 \%$ & $16 \%$ & & 4 \\
\hline 3. & C-S should be included as an integral part of the EFL lesson & $20 \%$ & $48 \%$ & $22 \%$ & $4 \%$ & $6 \%$ & 4 \\
\hline 4. & $\begin{array}{l}\text { Mother tongue and L1 should be separated in the EFL } \\
\text { classrooms strictly }\end{array}$ & $24 \%$ & $24 \%$ & $8 \%$ & $38 \%$ & $6 \%$ & 2 \\
\hline 5. & $\begin{array}{l}\text { C-S should only be used as a last option when no other } \\
\text { way is left }\end{array}$ & $22 \%$ & $44 \%$ & $18 \%$ & $8 \%$ & $8 \%$ & 4 \\
\hline 6. & $\mathrm{C}-\mathrm{S}$ is an efficient, time-saving technique & $24 \%$ & $50 \%$ & $20 \%$ & $6 \%$ & & 4 \\
\hline 7. & English is best taught in English only & $22 \%$ & $14 \%$ & $10 \%$ & $44 \%$ & $10 \%$ & 2 \\
\hline 8. & $\begin{array}{l}\text { The use of L1 in the EFL classrooms will result in } \\
\text { English decline }\end{array}$ & $24 \%$ & $10 \%$ & $6 \%$ & $50 \%$ & $10 \%$ & 2 \\
\hline 9. & The ideal teaching is in English & $24 \%$ & $42 \%$ & $8 \%$ & $26 \%$ & & 4 \\
\hline 10. & The more use of English, the better results for Learner & $20 \%$ & $40 \%$ & $14 \%$ & $24 \%$ & $2 \%$ & 4 \\
\hline
\end{tabular}

Table 1

The results shown in Table 1 demonstrate that most of the teachers' have positive attitudes regarding codeswitching practices in the college EFL Classrooms. However, some of the teachers' had shown concerns regarding the code-switching practices. $48 \%$ agreed that code-switching facilitates language learning. Meanwhile, $10 \%$ strongly disagreed. Another statement about C-S use can make students rely on teachers' $56 \%$ agreed and $16 \%$ disagreed.48\% agreed on making C-S as a fundamental part of learning only $10 \%$ did not agree to the statement. On the statement regarding L1 and L2 separation, 38\% agreed, and 6\% strongly agreed; however, $48 \%$ of them did not agree to the statement. Use of C-S when no option is left was agreed by $44 \%$ and strongly agreed by $22 \%$; meanwhile, $16 \%$ did not agree. $74 \%$ agreed that $\mathrm{C}$-S saves time in the EFL classroom, $6 \%$ disagreed, and 20\% went un-decided. Meanwhile, 54\% agreed that the best way to teach English is in English, so 
the C-S should be considered in need. 60\% disagreed that C-S lowers the English language standard, and 34\% agreed with the statement. Ideal teaching is in English was agreed by $66 \%$ of teachers,' and $26 \%$ disagreed. $60 \%$ agreed that successful learning depends on more English use; however, 26\% disagreed with the statement.

Objective 2: EFL teachers' perceptions about the functional use of code-switching Always (5), Often (4), Sometimes (3), Rarely (2), Never (1)

\begin{tabular}{|c|c|c|c|c|c|c|c|}
\hline No & $\begin{array}{l}\text { I switch English to students' } \\
\text { first language (L1) Sindhi/Urdu: }\end{array}$ & Always & Often & Sometime & Rarely & Never & Mode \\
\hline 1 & $\begin{array}{l}\text { To explain the meaning of new sentences and } \\
\text { words }\end{array}$ & $30 \%$ & $32 \%$ & $34 \%$ & $4 \%$ & & 3 \\
\hline 2 & To explain tough concepts & $48 \%$ & $40 \%$ & $10 \%$ & & $2 \%$ & 5 \\
\hline 3 & To explain grammar clearly & $32 \%$ & $46 \%$ & $20 \%$ & & $2 \%$ & 4 \\
\hline 4 & To check students' understanding & $24 \%$ & $22 \%$ & $30 \%$ & $20 \%$ & $4 \%$ & 3 \\
\hline 5 & To introduce unknown materials/topics & $26 \%$ & $36 \%$ & $22 \%$ & $8 \%$ & $8 \%$ & 4 \\
\hline 6 & $\begin{array}{l}\text { To explain the differences between L1 and L2 } \\
\text { of the student }\end{array}$ & $20 \%$ & $36 \%$ & $24 \%$ & $16 \%$ & $4 \%$ & 4 \\
\hline 7 & $\begin{array}{l}\text { To draw attention to the correct pronunciation } \\
\text { in English }\end{array}$ & $44 \%$ & $18 \%$ & $12 \%$ & $20 \%$ & $6 \%$ & 5 \\
\hline 8 & To organize classroom tasks & $30 \%$ & $32 \%$ & $14 \%$ & $16 \%$ & $8 \%$ & 4 \\
\hline 9 & $\begin{array}{l}\text { To keep classroom discipline and structure of } \\
\text { the lesson }\end{array}$ & $38 \%$ & $24 \%$ & $24 \%$ & $10 \%$ & $4 \%$ & 5 \\
\hline 10 & To provide Praise about students' performance & $34 \%$ & $32 \%$ & $18 \%$ & $10 \%$ & $6 \%$ & 5 \\
\hline 11 & $\begin{array}{l}\text { To encourage classroom Participation in } \\
\text { activities }\end{array}$ & $34 \%$ & $42 \%$ & $12 \%$ & $8 \%$ & $4 \%$ & 4 \\
\hline 12 & $\begin{array}{l}\text { To build interpersonal relationships among } \\
\text { students. }\end{array}$ & $30 \%$ & $54 \%$ & $8 \%$ & $4 \%$ & $4 \%$ & 4 \\
\hline 13 & $\begin{array}{l}\text { To reduce students' anxiety in learning } \\
\text { English }\end{array}$ & $36 \%$ & $30 \%$ & $24 \%$ & $2 \%$ & $8 \%$ & 5 \\
\hline 14 & $\begin{array}{l}\text { To increase students' motivation and } \\
\text { confidence }\end{array}$ & $54 \%$ & $16 \%$ & $14 \%$ & $6 \%$ & $10 \%$ & 5 \\
\hline
\end{tabular}

Table 2

Table 2 concludes that EFL college teachers' do not deny the role of code-switching for different purposes. The most common answers that teachers chose to reflect their positive views about the functional category of code-switching. $92 \%$ of teachers' agreed that they use C-S most frequent answer was sometimes. For complex concepts, $98 \%$ agreed to use, the most frequent answer given by teachers' was always. For checking grammar explanation, $98 \%$ agreed to use the statement's mode were often used for grammar checking. $76 \%$ use CS for checking students' understanding; however, the most frequent answer was sometimes. For unfamiliar material use, $84 \%$ use CS, frequently use was often. For explaining L1 \& L2 difference, $80 \%$ use CS while the most frequent use is often. For correct pronunciation, 74\% use CS, while the frequent use is always. For organizing classroom tasks, $76 \%$ use CS and the frequent use is often by teachers. To keep classroom discipline and structure of the lesson, $86 \%$ use CS, while the most frequent response was always. To provide Praise about students' performance, $84 \%$ use CS, and the most frequent answer given by the teacher was Always. For participation encouragement, $90 \%$ of teachers reported the use of CS, while frequent answers were often used. For interpersonal relationship building, 92\% reported using CS the frequent answer often used of CS. For overcoming students' anxiety while learning English, 90\% reported use while the frequent response was always use of CS. Teachers use of CS for students' motivation was reported $84 \%$ while the frequent response was always use of CS.

\section{Conclusion}

The results conclude that teachers having a solid commitment to the change as a higher proportion of teachers were found who shared positive feelings regarding Code-switching use. This shows extraordinary potential for incorporating other languages in education. If a teacher is committed to a particular cause, positive attitudes are likely to emerge, and their output will be improved.

Educators have positively agreed that they code-switch while delivering their lectures to help their students understand better. It is evident that the educators are positively driven and involved in the phenomenon of codeswitching, and college EFL teachers are using it. Overall, results give a strong indicator that code-switching can be one of the promising educational approaches to be implemented in the higher secondary education system of Sindh. 


\section{References}

Ahmed, A., \& Zareef, T. Tehseen.(2013). The role of medium of instruction used in Pakistani classrooms. Interdisciplinary Journal of Contemporary Research in Business, 4(12), 609-615

Biernacki, P., \& Waldorf, D. (1981). Snowball sampling: Problems and techniques of chain referral sampling. Sociological methods \& research, 10(2), 141-163.

Cheng, X. (2013). Research on Chinese College English Teachers' Classroom Code-switching: Beliefs and Attitudes. Journal of Language Teaching \& Research, 4(6).

Chowdhury, N. (2012). Classroom code switching of English language teachers at tertiary level: A Bangladeshi perspective. Stamford Journal of English, 7, 40-61.

Hall, G, \& Cook, G. (2013). Own-language use in ELT: exploring global practices and attitudes. ELT Research Papers, London: British Council.

He, S. U. N., Yussof, N., Vijayakumar, P., Gabrielle, L. A. I., O'BRIEN, B. A., \& Ong, Q. H. (2020). Teacher's code-switching and bilingual children's heritage language learning andcognitive switching flexibility. Journal of Child Language, 47(2), 309-336.

Lin, A. M. (2008). Code-switching in the classroom: Research paradigms and approaches.Encyclopedia of language and education, , 10, 273-286.

Losey, K. M. (2009). "Written Code-Switching in the Classroom: Can Research Resolve theTensions?" International Journal of Bilingual Education and Bilingualism, 12 (2): 213230.

Mahofa, E., \& Adendorff, S. A. (2014). Code switching in the learning of Mathematics word problems in Grade 10. Journal of Educational Studies, 13(2), 84-111.

Martin, H. E. (2005). Code - switching in US ethnic literature: multiple perspectives presented through multiple languages. Changing English, 12(3), 403-415.

Myers-Scotton, C. (1993). Common and uncommon ground: Social and structural factors codeswitching. Language in society, 475-503.

Selamat, J. T. (2014). Code switching in the Malaysian ESL classroom (Doctoral dissertation, University of Otago).

Smith, D. J. (2002). Patterns of variation in Spanish/English bilingualism in northeast Georgia. Talaat, M. (2005). Convergence and Social Context in Pakistani English. ELF Annual Research Journal, 4, 27-48

Van der Walt, C. (2009). The functions of code switching in English language learning classes. Per Linguam: a Journal of Language Learning = Per Linguam: Tydskrif vir Taalaanleer, 25(1), 30-43.

Younas, M., Afzaal, M., Noor, U., Khalid, S., \& Naqvi, S. (2020). Code Switching in ESL Teaching at University Level in Pakistan. English Language Teaching, 13(8), 63-73.

Yusuf, Y. Q. (2009). A Pragmatics Analysis of a Teacher's Code Code-switching in a Bilingual Classroom. Linguistics Journal, 4(2). 